\title{
New records of dragonflies and damselflies (Insecta: Odonata) from Amapá state, Brazil
}

\author{
Manoel Daltro Nunes Garcia Junior ${ }^{1 * \mathbb{D}}$, Monique Telcia dos Santos Damasceno ${ }^{2}{ }^{\mathbb{D}}$, Maria \\ Jeovana Lima Martins ${ }^{2}$, Tiago Silva da Costa ${ }^{1}{ }^{\circledR}$, Ricardo Marcelo dos Anjos Ferreira ${ }^{3(\mathbb{D}}$ \& \\ Raimundo Nonato Picanço Souto ${ }^{3}$ \\ ${ }^{1}$ Universidade Federal do Amapá, Programa de Pós-Graduação em Biodiversidade Tropical, Macapá, AP, \\ Brasil \\ ${ }^{2}$ Universidade Federal do Amapá, Instituto de Ciências Biológicas, Macapá, AP, Brasil \\ ${ }^{3}$ Universidade Federal do Amapá, Laboratório de Arthropoda, Campus Universitário Marco Zero do Equador, \\ Rodovia Juscelino Kubitschek de Oliveira, KM-02, Bairro Zerão, CEP 68902-280, Macapá, AP, Brasil \\ *Corresponding author: Manoel Daltro Nunes Garcia Junior, e-mail: m.d.juniorbio@gmail.com
}

GARCIA JUNIOR, M.D.N., DAMASCENO, M.T.S., MARTINS, M.J.L., COSTA, T.S., FERREIRA, R.M.A., SOUTO, R.N.P. New records of dragonflies and damselflies (Insecta: Odonata) from Amapá state, Brazil. Biota Neotropica 21(1): e20201074. https://doi.org/10.1590/1676-0611-BN-2020-1074

\begin{abstract}
The Odonata Order comprises one of the largest groups of aquatic insects, 7,000 species are described worldwide, with approximately 860 species registered in Brazil, around 14\% of the global fauna known to date. However, there are still great gaps in the knowledge of Odonata fauna in many areas of Brazil. This study aims to present the results of the survey of Odonata species sampled in three counties in the state of Amapá. The state is located in the north of the country, inserted in the Amazon Biome. Odonata were caught between January and December 2018, with 472 specimens being sampled, belonging to seven families, 36 genera and 53 species. In total, 27 of the species found during the study correspond to new records for the state of Amapá. Due to the lack of information on the diversity of the Odonata order in Amapá, the list of species presented should serve as input for new studies contributing to the knowledge of the order in the state.
\end{abstract}

Keywords: Inventory; Amazônia; Diversity; Fauna.

\section{Libélulas e donzelinhas (Insecta: Odonata) novos registros para o estado do Amapá, Brasil}

Resumo: A ordem Odonata compreende um dos maiores grupos de insetos aquáticos, mundialmente são descritas 7.000 espécies, sendo que, para o Brasil estão registradas aproximadamente 860 espécies, algo em torno de $14 \%$ da fauna global conhecida até o momento. No entanto, ainda existem grandes lacunas no conhecimento da odonatofauna em muitas áreas do Brasil. Este estudo tem como objetivo apresentar o resultado do levantamento de espécies de Odonata amostradas em três municípios do estado Amapá. O estado se encontra na região norte do país, inserido no Bioma amazônico. As capturas de Odonata foram realizadas entre os meses de janeiro e dezembro de 2018, sendo amostrados 472 espécimes pertencentes a sete famílias, 36 gêneros e 53 espécies. No total, 27 das espécies encontradas durante o estudo correspondem a novos registros para o estado do Amapá. Devido à falta de informação sobre a diversidade da ordem Odonata no Amapá, a lista de espécies apresentada deve servir de aporte para novos estudos contribuindo com o conhecimento da ordem no estado.

Palavras-chave: Inventário; Amazônia; Diversidade; Fauna. 


\section{Introduction}

The Odonata order comprises the second largest group of aquatic insects (Djikstra et al. 2014). In Brazil, the group has a great diversity of names, the most common being dragonfly, hyacinth and lava-bunda (Brasil \& Vilela 2019). The immatures are aquatic, and the adult individuals are winged terrestrial, organisms with predatory habits, both in their larval and adult stages (Corbet 1980).

Dragonflies occur on all continents, with the exception of Antarctica (Trueman 2007). Worldwide, the order comprises about 7,000 species (Kalkman et al. 2008), the number of species of Odonata in the neotropical region is close to 1,800 (Von Ellenrieder 2009), in Brazil 860 species are known, representing about $14 \%$ of the global fauna (Pinto 2018 ), or approximately $50 \%$ of the neotropical species.

Because of their close relationship with the aquatic environment, insects of the order Odonata are strongly affected by the physical and chemical changes in these environments, and some species of the order have environmental and ecological specificities for their occurrence (Nessimian et al. 2008). In particular, the species of the suborder Zygoptera are those that demonstrate the greatest environmental restrictions (Monteiro-Junior et al. 2014, 2015, Oliveira-Junior et al. 2015). These characteristics allow the use of dragonflies as bioindicators of the health of water bodies (Ferreira-Peruquetti \& De Marco 2002, Monteiro-Junior et al. 2015). Different factors have been affecting Odonata populations; according to Clausnitzer et al. (2009) one out of ten species of Odonata is threatened with extinction, among aquatic insects, dragonflies are one of the few organisms that have the conservation status evaluated in Brazil by ICMBIO and globally by IUCN.

Dragonflies are charismatic insects (Corbet 1999), easily observed and handled in the field (De Marco \& Vianna 2005). Even so, only $29 \%$ of the Brazilian territory presents data on the Odonata order (De Marco \& Vianna 2005). In recent years, several studies have been published, increasing even more the knowledge of odonatafauna in Brazil, especially in regions with lesser knowledge: Takiya et al. (2016) in the state of Ceará, Rodrigues \& Roque (2017) in Mato Grosso do Sul, Dalzochio et al. (2018) in Rio Grande do Sul, Koroiva et al. (2020) in Amazonas, Santos et al. (2020) in the state of Sergipe.

With the exception of the states of Amazonas and Pará, which have established large groups of studies with aquatic insects, studies with
Odonata are still scarce in the Brazilian Amazon. Among the states of the northern region, Acre, Amapá, Rondônia and Roraima have a high lack of knowledge about the order. Amapá has a large area of land destined for preservation, approximately $70 \%$ of its territory is protected environments (Oliveira 2010). Even with this large area preserved, the state has a high lack of knowledge for numerous groups; among them, the insects of the Odonata order stand out for the lack of information. Therefore, this study aims to present a list of Odonata species collected in three counties in the state, reporting a series of new occurrences.

\section{Material and Methods}

\section{Study area}

The collections were carried out in three counties (Table 1) in the state of Amapá, located in the Amazon region in northern Brazil (Figure 1). The climatic classification of the state according to Köppen is of the type Am (Tropical humid), the average annual temperature is $27^{\circ} \mathrm{C}$ and the average rainfall is $3330 \mathrm{~mm}$.

In Macapá, Odonata were collected in an environment of dry forest island (Ilha de Mata Seca), which according to Santos et al. (2013) is an area of less structural complexity, where the vegetation is small due to several factors. The part of forest sampled has approximately $6 \mathrm{Km}^{2}$ and is located in an urban area within the Campus Marco Zero of the Federal University of Amapá-UNIFAP. The Ilha de Mata has no connection with any water course; the collections of water when present are temporary, occurring more frequently in the rainiest period. Still in the county, collections were made in the Rio Curiaú Environmental Protection Area (Rio Curiaú APA). The APA has predominantly Cerrado areas, floodplain forest in addition to large extensions of flooded fields, and during the rainy season these environments flood completely and remain like this during much of the year (Chagas 1997). In Oiapoque, collections were carried out in the village of Clevelândia do Norte, which borders French Guiana. The village is located on the right bank of the Oiapoque River, about $5 \mathrm{~km}$ south of the urban area of the county. The environment is bordered by an area of primary forest, part of the Amazon Forest, and the dense forest of solid ground is predominant in the place. The sampling of Odonata in Porto Grande was carried out in the Amapá Forestry and Cellulose SA (AMCEL) area; the study region

Table 1. Location of points and type of environment sampled.

\begin{tabular}{|c|c|c|c|}
\hline Sample Point & County of Sample & Type of sampling environment & Coordinates \\
\hline P1 & Macapá & Brazilian Cerrado & $0^{\circ} 00^{\prime} 19.5^{\prime} \mathrm{S} 51^{\circ} 05^{\prime} 06.5^{\prime} \mathrm{W}$ \\
\hline $\mathrm{P} 2$ & Macapá & Brazilian Cerrado & $0^{\circ} 00^{\prime} 18.5^{\prime \prime} \mathrm{S} 51^{\circ} 05^{\prime} 14.0^{\prime \prime} \mathrm{W}$ \\
\hline P4 & Macapá & Lotic Environment & $0^{\circ} 16^{\prime} 17.5^{\prime \prime} \mathrm{N} 50^{\circ} 54^{\prime} 58.0^{\prime \prime} \mathrm{W}$ \\
\hline P5 & Macapá & Lotic Environment & $0^{\circ} 14^{\prime} 48.0^{\prime \prime} \mathrm{N} \mathrm{50} 57^{\prime} 26.4^{\prime \prime} \mathrm{W}$ \\
\hline P6 & Macapá & Floodplain & $0^{\circ} 11^{\prime} 21.7^{\prime \prime} \mathrm{N} 51^{\circ} 00 ’ 03.5$ 'W \\
\hline P8 & Oiapoque & Lotic Environment & 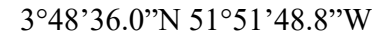 \\
\hline P9 & Oiapoque & Lotic Environment & $3^{\circ} 47^{\prime} 46.1^{\prime \prime} \mathrm{N} 51^{\circ} 51^{\prime} 47.9^{\prime \prime} \mathrm{W}$ \\
\hline $\mathrm{P} 10$ & Porto Grande & Lotic Environment & 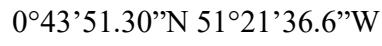 \\
\hline P11 & Porto Grande & Lotic Environment & 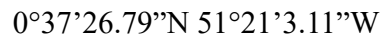 \\
\hline $\mathrm{P} 12$ & Porto Grande & Floodplain & $0^{\circ} 39^{\prime} 20.68^{\prime \prime} \mathrm{N} 51^{\circ} 22^{\prime} 49.8^{\prime \prime} \mathrm{W}$ \\
\hline
\end{tabular}



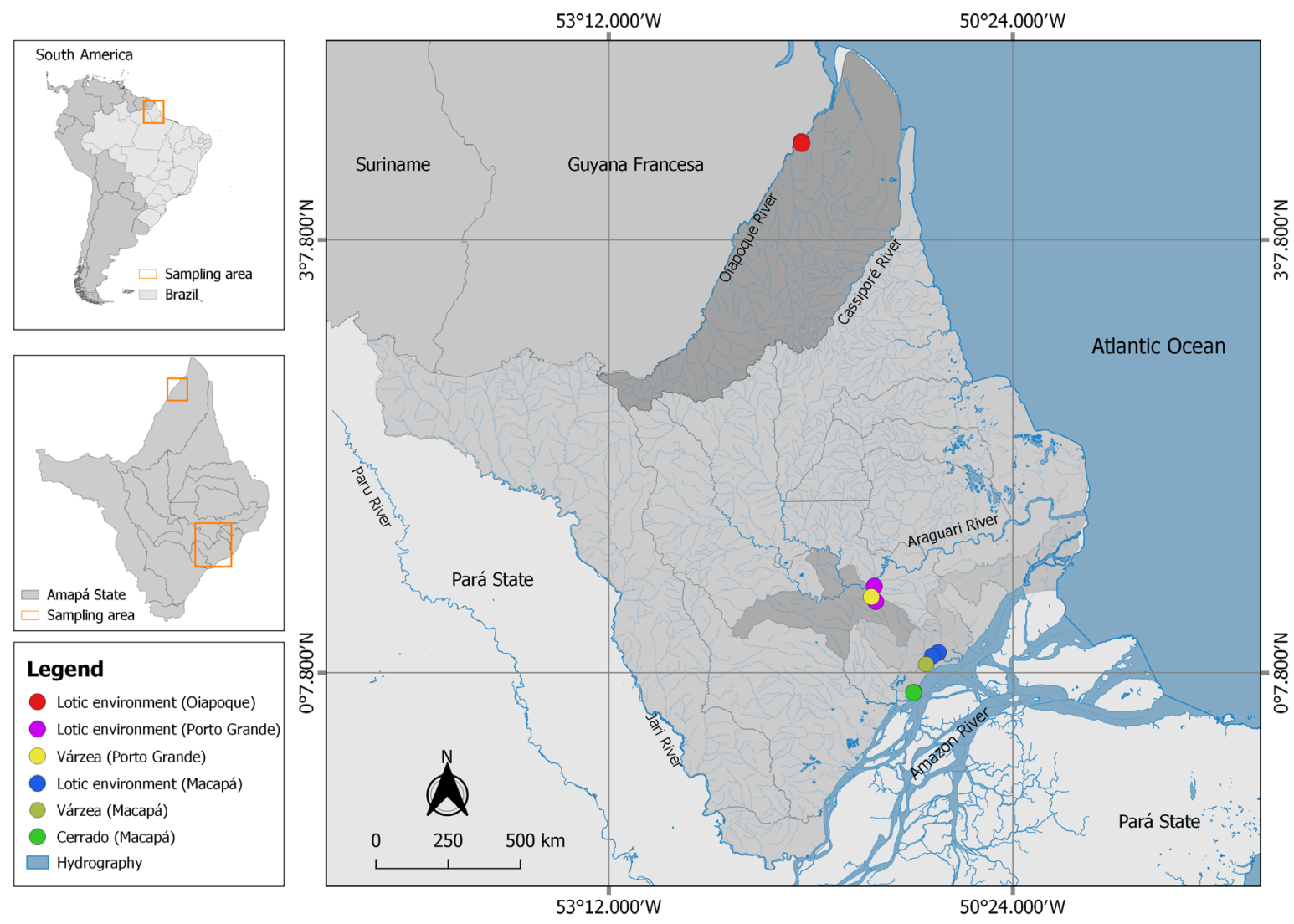

Figure 1. Map with the location of the counties of Macapá, Oiapoque and Porto Grande (AP) Brazil where the Odonata collections were carried out.

is formed by a mosaic comprising natural vegetation and extensive areas of monocultures, predominantly eucalyptus. According to Mustin et al. (2017) the natural vegetation occurring in the area comprises Amazonian savanna environments cut by stretches of gallery forests and flooded fields.

\section{Data collection}

The collections of Odonata were made between the months of January and December 2018. For the sampling of adults, entomological nets were used and the collections occurred between 10.00 and 16.00 P.M. of sunny days. The collected specimens were treated with acetone PA following the methodology proposed by Lencioni (2005), later identified according to the taxonomic keys of Garrison et al. (2006, $2010)$ and Lencioni $(2005,2006,2017)$ for genera and species, and additional Anisoptera literature pertinent to each genera to identify at the species level. The collected specimens were deposited in the ArthroLab entomological collection at the Federal University of Amapá-UNIFAP.

\section{Statistical analysis}

To measure the sampling effort and number of species collected, the non-parametric Jackknifel estimator was used, and the rarefaction curve was generated from the estimator. Jackknife 1 and the rarefaction curve were calculated using software $R$ (R Core Team 2019) using the vegan package (Oksanen et al. 2019).

\section{Results}

In total, 472 specimens belonging to seven families, 36 genera and 53 species were sampled ( Table 2), with 27 of the species found during the study corresponding to new records for the state of Amapá. Among the sampled families, Libellulidae showed the greatest diversity of species $(n=27)$, followed by Coenagrionidae $(n=17)$, Calopterygidae $(\mathrm{n}=3)$, Aeshnidae, Gomphidae and Heteragrionidae $(\mathrm{n}=2)$ and Dicteriadidae with one species.

The individuals of the suborder Anisoptera represented the greatest abundance of collected specimens $(\mathrm{n}=280)$, followed by Zygoptera ( $\mathrm{n}$ =192). Among the Anisoptera, the family Libellulidae was the one that comprised the largest number of captured specimens $(n=269)$. The most abundant families among the Zygoptera were Coenagrionidae ( $\mathrm{n}$ $=150)$, Calopterygidae $(\mathrm{n}=26)$ and Heteragrionidae $(\mathrm{n}=15)$. The most representative genera were Erythrodiplax $(\mathrm{n}=67)$, Ischnura $(\mathrm{n}=46)$ and Orthemis $(\mathrm{n}=36)$. Among the sampled species Miathyria marcella (Selys in Sagra, 1854) $(\mathrm{n}=29)$, Erythrodiplax umbrata (Linnaeus, 1758) $(\mathrm{n}=28)$ and Ischnura fluviatilis Selys, $1876(\mathrm{n}=24)$ were the ones with the highest number of collected individuals.

The rarefaction curve, based on the analysis of the data sampled during the study, showed good results for the sampling efforts, the collection efficiency was close to $84 \%$. The Jackknife 1 estimator (Figure 2) demonstrated that the richness of species found corresponded to $73 \%( \pm 1,4)$. 
Garcia Junior, MDN. et al.

Table 2. List of species registered for the state of Amapá. Location of the collection points present in table 1. ICMBIO red book status 2019, LC (Least Concern) and DD (Insufficient Data). * New records for the State.

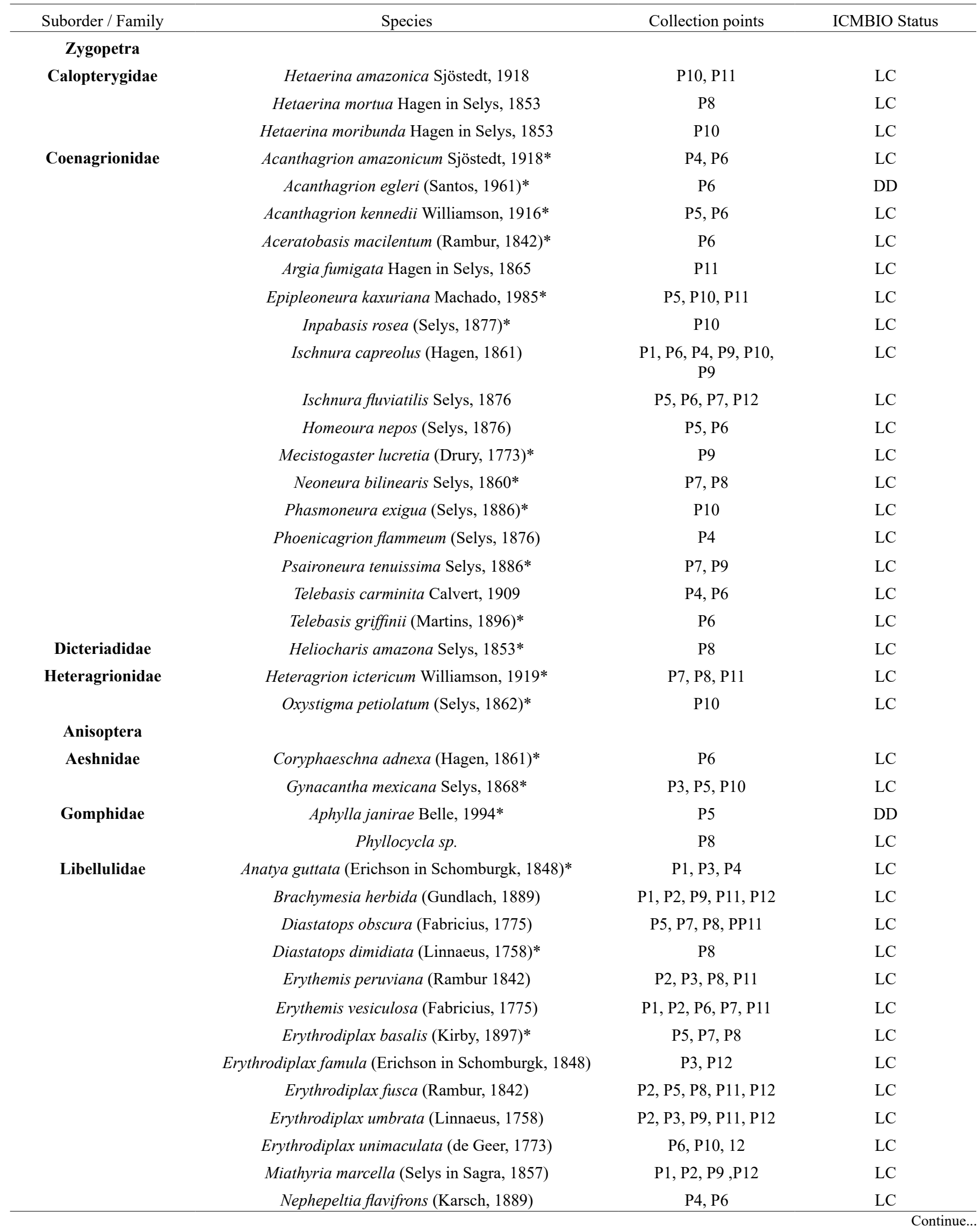


New records of Odonata from Amapá state, Brazil

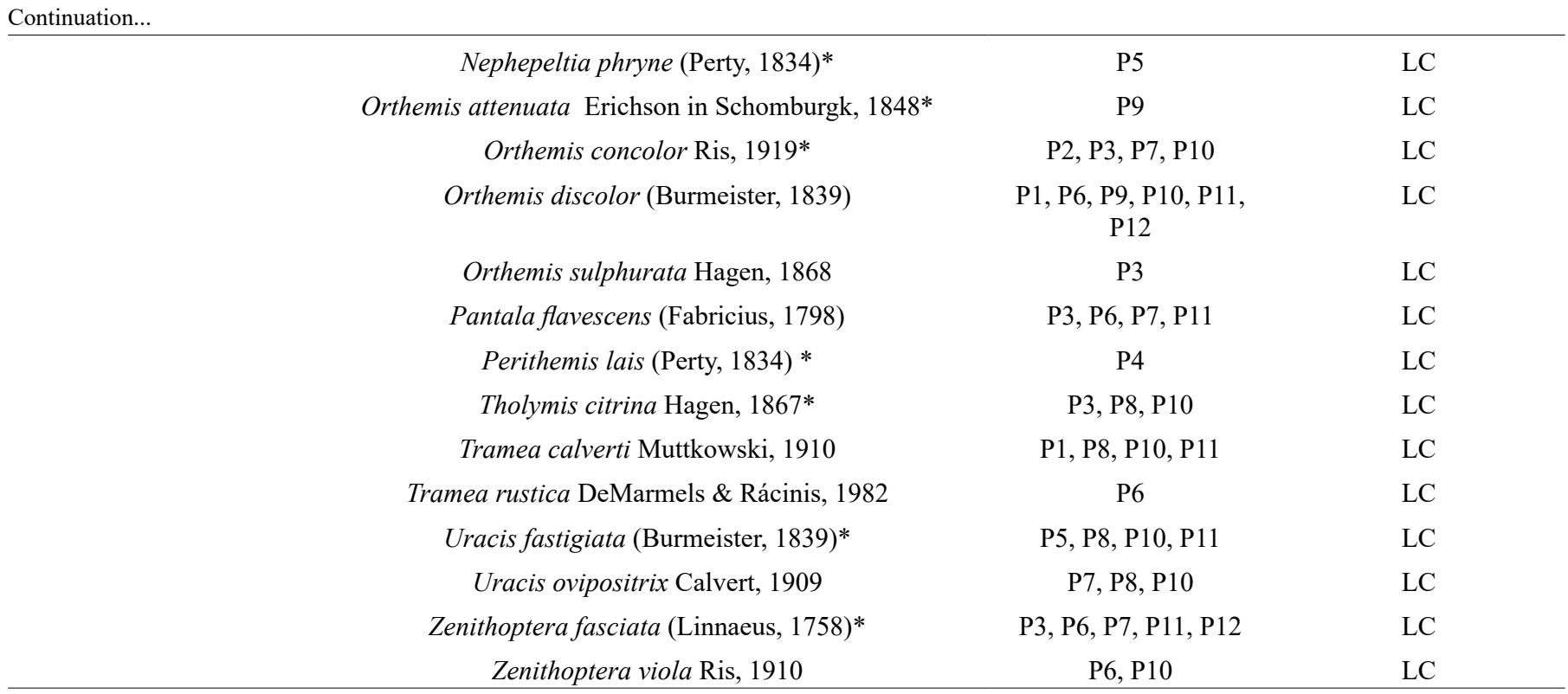

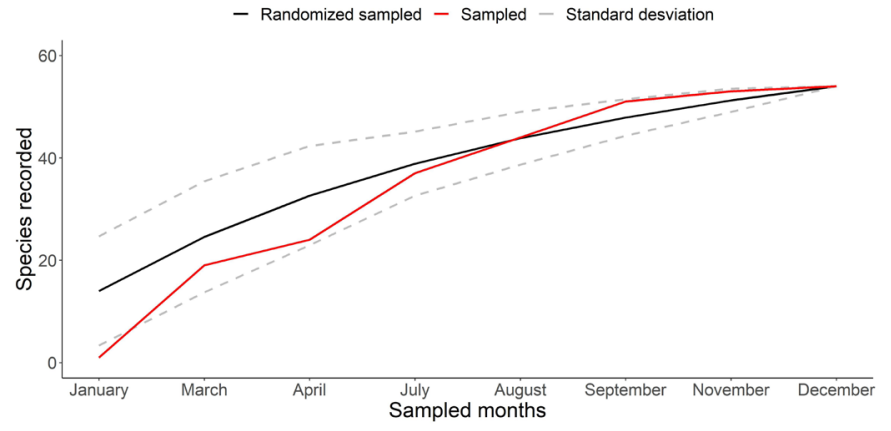

Figure 2. Rarefaction curve and its confidence interval (95\% CI) of Odonata species collected in the counties of Macapá, Oiapoque and Porto Grande (AP), Brazil.

\section{Discussion}

The study was carried out in a small sample area in three counties in the state of Amapa; in total 53 species were found, a result that suggests that the region's Odonata fauna is relatively richer. Representatives of the suborder Anisoptera comprised approximately $60 \%$ of the samples sampled, with 280 specimens collected, the Libellulidae family $(\mathrm{n}=$ 269) was the most abundant during the study. This high number can be explained by the fact that many species of this family are opportunistic organisms (Costa \& Oldrini 2005, Boti et al. 2007), frequently prevalent in open vegetation environments (Dutra \& De Marco 2015, Rodrigues \& Roque 2017) or even in anthropized environments (Damaceno et al. 2014). This fact is due to its ability to control body temperature (Corbet \& May 2008), in addition to having great dispersion capacity (Monteiro-Júnior et al. 2013, Oliveira Júnior et al. 2017).

The families Aeshnidae and Gomphidae had only two species collected each, totaling 11 individuals sampled, eight specimens belonging to Aeshnidae and three to Gomphidae.This low number can be associated with the flight habits of these organisms, which are usually extremely fast. In addition, species of Aeshnidae usually reach great heights and some species are crepuscular (Bedê et al. 2000), a fact that

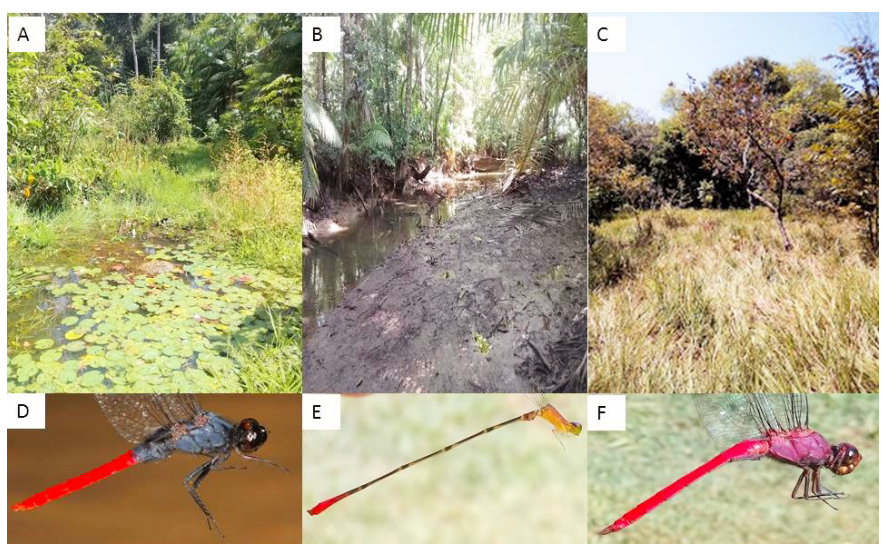

Figure 3. Sample locations: A, Macapá, Rio Curiaú Environmental Protection Area - APA do Curiaú; B, Porto Grande, Amapá Forestry and Cellulose SA (AMCEL); C, Macapá, Ilha de Mata seca in the Amazon savanna. Odonata: D, Libellulidae, Erythemis peruviana (Rambur, 1842); E, Coenagrionidae, Psaironeura tenuissima Selys, 1886 and Libellulidae, F, Orthemis discolor (Burmeister, 1839).

makes it difficult to capture them. According to Almeida et al. (2013) these low numbers may be linked to the type of collection performed, a diversification of sampling methods may allow obtaining species rarely captured using the standard methodology.

Coenagrionidae, the family with the largest number of species for the suborder Zygoptera in Brazil (Lencioni 2006), presented the greatest diversity of species $(=17)$ and abundance $(n=150)$ among zygopterans, with almost $78 \%$ of the collected specimens. The genera Ischnura, Acanthagrion and Telebasis with 46, 22 and 22 individuals collected respectively were the most abundant for the family, comprising approximately $60 \%$ of the Coenagrionidae sampled. The specimens of these genera are highly representative organisms in many studies and in different environments such as: (Cerrado, Ferreira-Peruquetti \& Fonseca-Gessner 2003, Borges et al. 2019; Veredas, Vilela et al. 2016; Pampa, Garcia Junior et al. 2019; Atlantic Forest, Ferreira-Peruquetti \& De Marco 2002). 
With the exception of Oxystigma petiolatum (Selys, 1862) (Heteragrionidae) and Mecistogaster lucretia (Drury, 1773) (Coenagrionidae) found exclusively within the forest area during this study, the other specimens of zygopterans were collected close to water bodies, generally in shaded areas. This fact can be attributed to ecophysiological restrictions of the group (Corbet 1999). These organisms generally have a small size, which represents a high conductance, so they tend to look for places with less thermic variation, such as places with less sunlight (Brasil et al. 2019).

Most of the species found during the study, according to De Marco et al. (2018) in the red book of Brazilian fauna threatened with extinction fall into the level of least concern. However, Aphylla janirae Belle, 1994 and Acanthagrion egleri (Santos, 1961) are species that have insufficient data to classify the level of vulnerability; these new distribution records may contribute in the future to the threat level of these species.

In conclusion the diversity of Odonata found and the report of the new occurrence records for the state indicate that the fauna of the region deserves more attention, and the establishment of new collection points can further expand the list of species occurring in Amapá.

\section{Acknowledgements}

This study was partially supported by $\mathrm{CNPq}$ (Conselho Nacional de Desenvolvimento Científico e Tecnológico) and FAPEAP (Fundação de Amparo a Pesquisa do Estado do Amapá).

\section{Author Contributions}

Manoel Daltro Nunes Garcia Junior: Substantial contribution in the concept and design of the study. Contribution to data collection. Contribution to data analysis and interpretation. Contribution to manuscript preparation. Contribution to critical revision, adding intellectual content.

Monique Telcia dos Santos Damasceno: Contribution to data collection. Contribution to manuscript preparation.

Maria Jeovana Lima Martins: Contribution to data collection. Contribution to manuscript preparation.

Tiago Silva da Costa: Contribution to data analysis and interpretation. Contribution to manuscript preparation. Contribution to critical revision, adding intellectual content.

Ricardo Marcelo dos Anjos Ferreira: Contribution to data analysis and interpretation. Contribution to manuscript preparation. Contribution to critical revision, adding intellectual content.

Raimundo Nonato Picanço Souto: Substantial contribution in the concept and design of the study. Contribution to data analysis and interpretation. Contribution to manuscript preparation. Contribution to critical revision, adding intellectual content.

\section{Conflicts of Interest}

The authors declare that they have no conflict of interest related to the publication of this manuscript.

\section{References}

ALMEIDA, M.V.O., PINTO, A.P., CARVALHO, A.L. \& TAKIYA, D.M. 2013. When rare is just a matter of sampling: unexpected dominance of clubtail dragonflies (Odonata, Gomphidae) through different collecting methods at Parque Nacional da Serra do Cipó, Minas Gerais State, Brazil. Rev. Bras. Entomol. 57:417-423.

BEDÊ, L.C., PIPER, W., PETERS, G. \& MACHADO, A.B.M. 2000. Phenology and oviposition behaviour of Gynacantha bifida Rambur in Brazil (Anisoptera: Aeshnidae). Odonatologica 29: 317-324.

BORGES, L.R., BARBOSA, M.S., CARNEIRO, M.A.A., VILELA, D.S. \& SANTOS, J.C. 2019. Dragonflies and damselflies (Insecta: Odonata) from a Cerrado area at Triângulo Mineiro, Minas Gerais, Brazil. Biota Neotrop. 19(1): e20180609. http://dx.doi.org/10.1590/1676-0611-BN-2018-0609

BOTI, J.B., TOLEDO, L.O., HADDADE, I.R., BOTI, D.R. \& OLIVEIRA, B.R. 2007. Libélulas (Odonata: Insecta) como indicadoras de poluição do córrego São Silvano, Colatinas, ES. Anais do VII Congresso de Ecologia do Brasil. Disponível em: http://www.seb-ecologia.org.br/viiiceb/trabalhos.html.

BRASIL, L.S. \& VILELA, D.S. 2019. Peculiaridades regionales en la percepción de brasileños sobre las libélulas: nomenclatura popular y conservación. Hetaerina. 1:15-20.

BRASIL, L.S., SILVERIO, D.V., CABETTE, H.S.R., BATISTA, J.D., VIEIRA, T.B., DIAS-SILVA, K. \& JUEN, L. 2019. Net primary productivity and seasonality of temperature and precipitation are predictors of the species richness of the Damselflies in the Amazon. Basic Appl. Ecol. 35: 45-53.

CHAGAS, M.A. 1997. Curiaú: Dossiê da Área de Proteção Ambiental: dossiê. Macapá: GEA/SEMA.

CLAUSNITZER, V., KALKMAN, V.J., RAM, M., COLLEN, B., BAILLIE, J.E.M., BEDJANIČ, M., DARWALL, W.R.T., DIJKSTRA, K.D.B., DOW, R., HAWKING, J., KARUBE, H., MALIKOVA, E., PAULSON, D., SCHÜTTE, K., SUHLing, F., VIllanUEVA, R. J., VON ELLENRIEDER, N. \& WILSON, K. 2009. Odonata enter the biodiversity crisis debate: The first global assessment of an insect group. Biol. Conserv. 142:1864-1869.

COSTA, J.M. \& OLDRINI, B.B. 2005. Diversidade e distribuição dos Odonata (Insecta) no Estado do Espírito Santo, Brasil. Publicações Avulsas do Mus. Nac. 107: 1-15.

CORBET, P.S. 1980. A biology of Odonata. Ann. Rev. Ent. 25: 189-217.

CORBET, P.S. 1999. Dragonflies: behavior and ecology of Odonata. Ithaca: Comstock Publ. 829 p.

CORBET, P.S. \& MAY, M.L. 2008. Fliers and perchers among Odonata: dichotomy or multidimensional continuum? A provisional reappraisal. Int. J. Odonatol. 11: 155-71.

DALZOCHIO, M.S., RENNER, S., SGANZERLA, C., PRASS, G., ELY, G.J., SALVI, L.C., DAMETTO, N. \& PÉRICO, E. 2018. Checklist of Odonata (Insecta) in the state of Rio Grande do Sul, Brazil with seven new records. Biota Neotrop. 18(4):e20180551. DOI: 10.1590/1676- 0611-bn2018-0551

DAMACENO, I.V., BUYS, S.C., SILVA, C.C. \& MARTINS, R. F. 2014. Levantamento de Odonata (Insecta) ao longo das margens do Rio Dois de Setembro, Município de Ecoporanga, noroeste do Estado do Espirito Santo. Bol. do Museu Mello Leitão. 33: 25-33.

DE MARCO P.JR. \& VIANNA D.M. 2005. Distribuição do esforço de coleta de Odonata no Brasil - subsídios para escolha de áreas prioritárias para levantamentos faunísticos. Lundiana 6:13-26.

DE MARCO, P.JR., JUEN, L., BATISTA, J.D., FURIERI, K.S. \& NEISS, U.G. 2018. Livro Vermelho da Fauna Brasileira Ameaçada de Extinção: Volume VII. Invertebrados (Odonata). Brasilia: ICMBio/MMA

DIJKSTRA, K.B., MONAGHAN, M.T. \& PAULS, S.U. 2014. Freshwater Biodiversity and Aquatic insect diversification. Annu. Rev. Entomol. 59(1): 143-163.

DUTRA, S. \& DE MARCO, P.JR. 2015. Bionomic differences in odonates and their influence on the efficiency of indicator species of environmental quality. Ecol. Indic. 49: 132-142. 
FERREIRA-PERUQUETTI P.S. \& DE MARCO, P.JR. 2002. Efeito da alteração ambiental sobre comunidades de Odonata em riachos de Mata Atlântica de Minas Gerais, Brasil. Rev. Bras. Zool. 19 (2): 317 - 327.

FERREIRA-PERUQUETTI, P. \& FONSECA-GESSNER, A.A. 2003. Comunidade de Odonata (Insecta) em áreas naturais de Cerrado e monocultura no nordeste do Estado de São Paulo, Brasil: relação entre o uso do solo e riqueza faunística. Rev. Bras. Zool. 20(2): 219-224.

GARCIA JUNIOR, M.D.N., RAKES, M., PAZINI, J. DE B., PASINI, R.A., FLÁVIO R.M. GARCIA, F.R.M. \& GRÜTZMACHER, A.D.D. 2019. The diversity of Odonata adults's at Pampa Biome from Brazil. Rev. Biol. Trop. 67(1): 107-117.

GARRISON, R.W., VON ELLENRIEDER, N. \& LOUTON, J.A. 2006. Dragonfly genera of the new world: an illustrated and annotated key to the Anisoptera. The John Hopkins University Press, Baltimore, USA, 368 p.

GARRISON, R.W., VON ELLENRIEDER, N. \& LOUTON, J.A. 2010 Damselfly genera of the new world: an illustrated and annotated key to the Zygoptera. The John Hopkins University Press Baltimore, USA, 490 p.

KALKMAN, V.J., CLAUSNITZER, V., DIJKSTA, K.D.B., PAULSON, R. \& VANTOL, J. 2008. Global diversity of dragonflies (Odonata) in freshwater. Hydrobiologia 595: 351-363.

KOROIVA, R., NEISS, U.G., FLECK, G. \& HAMADA, N. 2020. Checklist of dragonflies and damselflies (Insecta: Odonata) of the Amazonas state, Brazil. Biota Neotrop. 20:1. https://doi.org/10.1590/1676-0611-bn-2019-0877

LENCIONI, F.A.A. 2005. The Damselflies of Brazil: An Illustrated Identification Guide 1 - The Noncoenagrionidae families. All Print Editora, São Paulo, Brazil, $324 \mathrm{p}$.

LENCIONI, F.A.A. 2006. The Damselflies of Brazil: An Illustrated Identification Guide 2 - Coenagrionidae. All Print Editora, São Paulo, Brazil, 419 p.

LENCIONI, F.A.A. 2017. Damselflies of Brazil - an illustrated identification guide - Southeast region. E-book, $559 \mathrm{p}$.

MONTEIRO-JÚNIOR, C.S., COUCEIRO, S.R.M., HAMADA, N. \& JUEN, L. 2013. Effect of vegetation removal for road building on richness and composition of Odonata communities in Amazonia, Brazil. Int. J. Odonatol. 16: 135-144. https://doi.org/10.1080/13887890.2013.764798

MONTEIRO-JUNIOR, C.S., JUEN, L. \& HAMADA, N. 2014. Effects of urbanization on stream habitats and associated adult dragonfly and damselfly communities in central Brazilian Amazonia. Landsc. Urban Plan. 127: 28-40

MONTEIRO-JÚNIOR, C.S., JUEN, L. \& HAMADA, N. 2015. Analysis of urban impacts on aquatic habitats in the central Amazon basin: adult odonates as bioindicators of environmental quality. Ecol. Indicators. 48: 303-11.

MUSTIN, K., CARVALHO, W. D., HILÁRIO, R. R., COSTA-NETO, S. V., SILVA,C., VASCONCELOS, I. M., CASTRO, I. J., EILERS, V., KAUANO, É. E., MENDES-JUNIOR, R. N. G., FUNI, C., FEARNSIDE, P. M., SILVA, J. M. C., EULER, A. M. C., \& TOLEDO, J. J. 2017. Biodiversity, threats and conservation challenges in the Cerrado of Amapá, an Amazonian savanna. Nature Cons. 22:107-127.

NESSIMIAN, J.L., VENTICINQUE, E.M., ZUANON, J., DE MARCO, JR. P., GORDO, M., FIDELIS, L., BATISTA, J.D. AND JUEN, L. 2008. Land use, habitat integrity, and aquatic insect assemblages in Central Amazonian streams. Hydrobiologia. 614: 117-131.
OKSANEN, J., BLANCHET, F.G., FRIENDLY, M., KINDT, R., LEGENDRE, P., MCGLINN, D., MINCHIN, P.R., O'HARA, R.B., SIMPSON, B.L., SOLYMOS, P., STEVENS, M.H.H., SZOECS, E. \& WAGNER, H. 2019 vegan: Community Ecology Package. R package version 2.5-5. https:// CRAN.R-project.org/package=vegan

OLIVEIRA, M.J. 2010. Diagnóstico do setor mineral do Estado do Amapá. Instituto de Pesquisas Cientificas e Tecnológicas do Estado do Amapá Macapá, $152 \mathrm{p}$.

OLIVEIRA-JUNIOR, J.M.B., SHIMANO, Y., GARDNER, T.A., HUGHES, R.M., DE MARCO, P.JR. \& JUEN, L. 2015. Neotropical dragonflies (Insecta: Odonata) as indicators of ecological condition of small streams in the eastern Amazon. Austral Ecol. 40(6): 733-744.

OLIVEIRA-JÚNIOR, J.M.B., MARCO P.JR., DIAS-SILVA, k., LEITÃO, R.P., LEAL, C.G., POMPEU, P.S., GARDNER, T.A., HUGHES, R.M. \& JUEN, L. 2017. Effects of human disturbance and riparian conditions on Odonata (Insecta) assemblages in eastern Amazon basin streams. Limnologica. 66: 31-39. https://doi.org/10.1016/j.limno.2017.04.007

PINTO, A.P. 2018. Odonata in Catálogo Taxonômico da Fauna do Brasil. PNUD. http://fauna.jbrj.gov.br/fauna/faunadobrasil/171 (last access on 04/22/2020).

R CORE TEAM. 2019. R: A language and environment for statistical computing. R Foundation for Statistical Computing, Vienna, Austria. URL https:// www.R-project.org/

RODRIGUES, M.E. \& ROQUE, F.O. 2017. Checklist de Odonata do Estado de Mato Grosso do Sul, Brasil. Iheringia Sér. Zool. 117: 107-111.

SANTOS, N.M.C., VALE-JÚNIOR, J.F. \& BARBOSA, R.I. 2013. Florística e estrutura arbórea de ilhas de mata em áreas de savana do norte da Amazônia brasileira. Bol. Mus. Para. Emílio Goeldi. Cienc. Nat. 8: 205-221.

SANTOS, J.C., VILELA, D.S., DE ALMEIDA, W.R., SANTOS, B., SANTOS, A.E., BEZERRA, L.M.M., SANTOS, L., NETO, A.M.S., VENÂNCIO, H \& CARNEIRO, M.A.A. 2020. A rapid survey of dragonflies and damselflies (Insecta: Odonata) reveals 29 new records to Sergipe State, Brazil. Hetaerina. 2: 29-34.

TAKIYA, D.M., SANTOS, A.P.M., PINTO, A.P., HENRIQUES-OLIVEIRA, A.L., CARVALHO, A.L., SAMPAIO, B.H.L., CLARLSON, B., MOREIRA, F.F.F., AVELINO-CAPISTRANO, F., GONÇALVES, I.C., CORDEIRO, I.R.S., CÂMARA, J.T., BARBOSA, J.F., SOUZA, R.M. \& RAFAEL, J.A. 2016. Aquatic Insects from the Caatinga: checklists and diversity assessments of Ubajara (Ceará State) and Sete Cidades (Piauí State) National Parks, Northeastern Brazil. Biodiv. Data J. 4: e8354. http://dx.doi. org/10.3897/BDJ.4.e8354

TRUEMAN, J.W.H. 2007. A brief history of the classification and nomenclature of Odonata. Zootaxa , 1668: 381-394.

VILELA, D.S., GUILLERMO-FERREIRA, R. \& DEL-CLARO, K. 2016. The Odonata community of a Brazilian vereda: Seasonal patterns, species diversity and rarity in a palm swamp environment. Biosci. J. 32: 486-495.

VON ELLENRIEDER, N. 2009. Databasing dragonflies: state of knowledge in the Neotropical region. Agrion 13: 58-72.

Received: 01/07/2020

Revised: 05/10/2020

Accepted: 26/10/2020

Published online: 07/12/2020 